\title{
What is Project Success: A Literature Review
}

\author{
Guru Prakash Prabhakar \\ Bristol Business School \\ University of the West of England \\ Coldharbour Lane, Frenchay Campus \\ Bristol- BS16 1QY, UK
}

Tel: 44-117-328-3461_E-mail: guru.prabhakar@uwe.ac.uk

\begin{abstract}
Most of the projects we hear of in media are either over budget, late or are simply not good enough and still different lobbies of people claim that those projects have been successful. Neither the practitioners nor the academicians seem to agree on what constitutes project success. It seems to be a rather elusive concept. This paper attempts to put forth the points of views of different researchers in this field.
\end{abstract}

Keywords: Project Success, Project Manager

There is wide divergence of opinions in this field; the only agreement seems to be the disagreement on what constitutes 'project success'. (Murphy, Baker \& Fisher, 1974; Pinto \& Slevin 1988; Gemuenden \& Lechler, 1997 and Shenhar, Levy, and Dvir 1997).

De Wit (1988) and other writers distinguish between project success (measured against the overall objectives of the project) and project management success (measured against the widespread and traditional measures of performance against cost, time and quality). The second distinction is also important - it is the difference between success criteria (the measures by which success or failure of a project or business will be judged) and success factors (those inputs to the management system that lead directly or indirectly to the success of the project or business).

Rockart (1979) developed a three step procedure for determining which factors contribute to meeting organizational goals. His study reveals that many executives tend to link in terms of "what does it take to be successful" in their business rather than in terms of purposes, objectives, and goals. Consequently the key question in this method is, "what does it take to be successful in the business?" The three main steps in the process are:

Generate critical success factors (CSFs): The key question in this step is, "what does it take to be successful in the business?"

Refine (CSFs) into objectives: The key question in this step is, "What should the organization's objectives and goals be with respect to the critical success factors?"

Identify measures of performance: The key question in this step is, "How will we know whether the organization has been successful on this factor?"

Rockart (1979) and his associates applied the CSF method at several different organizations. Table 1 below is an example obtained from Microwave Associates:

Table 1. A list of Critical success factors

\begin{tabular}{|l|l|}
\hline Critical Success Factors (CSFs) & Prime Measures \\
\hline Image in financial markets & Price/earnings ratio \\
\hline Technological reputation with customers & $\begin{array}{l}\text { Orders/bid ratio } \\
\text { Customer "perception" interview results }\end{array}$ \\
\hline Market success & $\begin{array}{l}\text { Change in market share (product wise) } \\
\text { Growth rates of company markets }\end{array}$ \\
\hline Risk recognition in major bids and contracts & $\begin{array}{l}\text { Company's years of experience with similar products } \\
\text { "New" or "old" customer } \\
\text { Prior customer relationship }\end{array}$ \\
\hline Profit margin on jobs & Bid profit margin as ratio of similar jobs in this product line \\
\hline Company morale & Turnover, absenteeism etc. \\
\hline Performance to budget on major jobs & Job cost, budgeted/actual ratio \\
\hline
\end{tabular}


Rowe, Mason and Dickel (1982) say that "Key result areas (KRAs) and critical success factors (CSFs) provide clues that help to answer the question of whether the organization is able to effectively mobilize its resources where there are conflicting sub goals, environmental uncertainty, and internal politics and constraints".

Verma $(1995,1996)$ writes that communication, teamwork, and leadership are vital components of effective management of project human resources and are necessary to accomplish project objectives successfully. Crawford (2002) describes success in the following way:

"A perception... "And; "The project meets the technical performance specifications and/or mission to be performed, and if there is a high level of satisfaction concerning the project outcomes...."

Cleland (1986) suggested that "project success is meaningful only if considered from two vantage points: the degree to which the project's technical performance objective was attained on time and within budget; the contribution that the project made to the strategic mission of the enterprise."

Freeman and Beale (1992) provided an interesting example of the different points of view of people: "An architect may consider success in terms of aesthetic appearance, an engineer in terms of technical competence, an accountant in terms of dollars spent under budget, a human resources manager in terms of employee satisfaction, and chief executive officers rate their success in the stock market." Freeman and Beale (1992) reviewed the project management literature, identified seven main criteria for measuring the success of projects; five of them are more frequently used than others:

Technical performance

Efficiency of execution

Managerial and organizational implications (mainly customer satisfaction)

Personal growth, and

Manufacturability and business performance

Project success may be assessed by different interest groups-stockholders, managers, customers, employees, and so on. Criteria for measuring project success must therefore reflect different views (Stuckenbruck, 1986).

Baccarini (1999) identified two distinct components of project success:

Project management success-- This focuses upon the project process and, in particular, the successful accomplishment of cost, time, and quality objectives. It also considers the manner in which the project management process was conducted.

Product success--This deals with the effects of the project's final product.

It is common for project management literature to confusingly intertwine these two separate components of project success and present them as a single homogenous group. In order to properly define and assess project success, a distinction should be made between product success and project management success, as they are not the same. Pinto \& Slevin (1988) after sampling over 650 project managers, the researchers concluded that "project success" is something much more complex than simply meeting cost, schedule, and performance specifications. In fact client satisfaction with the final result has a great deal to do with the perceived success or failure of projects. Further, Baker, Murphy and Fisher $(1983,1988)$ conclude:

"In the long run, what really matters is whether the parties associated with, and affected by, a project are satisfied. Good schedule and cost performance means very little in the face of a poor performing end product."

In the words of Baker et al. (1983): "instead of using time, cost and performance as measures for project success, perceived performance should be the measure."

Clarke (1999) also states that by targeting the main problems and issues using the key success factors as a focus could make a significant difference to the effectiveness of project management. In order to ensure that a project is completed successfully, project plans need to be updated regularly.

He continues to profess that success will be measured more easily when the objectives are clearly stated at the outset of the project.

Ward (1995) opines that: "scope and objectives are the guiding principles that direct the efforts of the project team and they will determine a project's success or failure".

According to Radolph \& Posner (1994), having a few key objectives focuses the team on the target and creates commitment and agreement about the project goals. Richardson (1995) \& King (1996) think that none of the key success factors described in the literature are responsible, on their own, for ensuring a project's success- they are all 
inter-dependent and require a holistic approach to be taken. Groups of success factors and their interactions are of prime importance in determining a project's success or failure.

Belassi and Tukel (1996) grouped the success factors listed in the literature and described the impact of these factors on project performance. They grouped the factors into four areas:

Factors related to the project

Factors related to the project managers and the team members

Factors related to the organization

Factors related to the external environment.

In their second part of the research with a total of 57 responses, many project manager related factors have been found to be critical. In contrast with a previous finding using 91 responses, a noticeable shift in ranking from organizational factors towards factors related to project managers and team members was witnessed with project managers related factors dominating over the organizational factors. They came out with some important relationships as well. For example, when time is used to measure project success, then a project manager's skills and communication between the team members become critical.

"in previous studies it was assumed that if a project's completion time exceeds its due date, or expenses overran the budget, or outcomes did not satisfy a company's predetermined performance criteria, the project was assumed to be a failure. Today we know that determining whether a project is a success or failure is far more complex."

To come up with all possible critical factors that might affect outcome is impossible because of the diversity of projects. But to identify the groups to which the critical factors belong would be sufficient for better evaluation of projects.

Table 2. Seven lists of critical success factors developed in the literature tabulated by Belassi \& Tukel (1996).

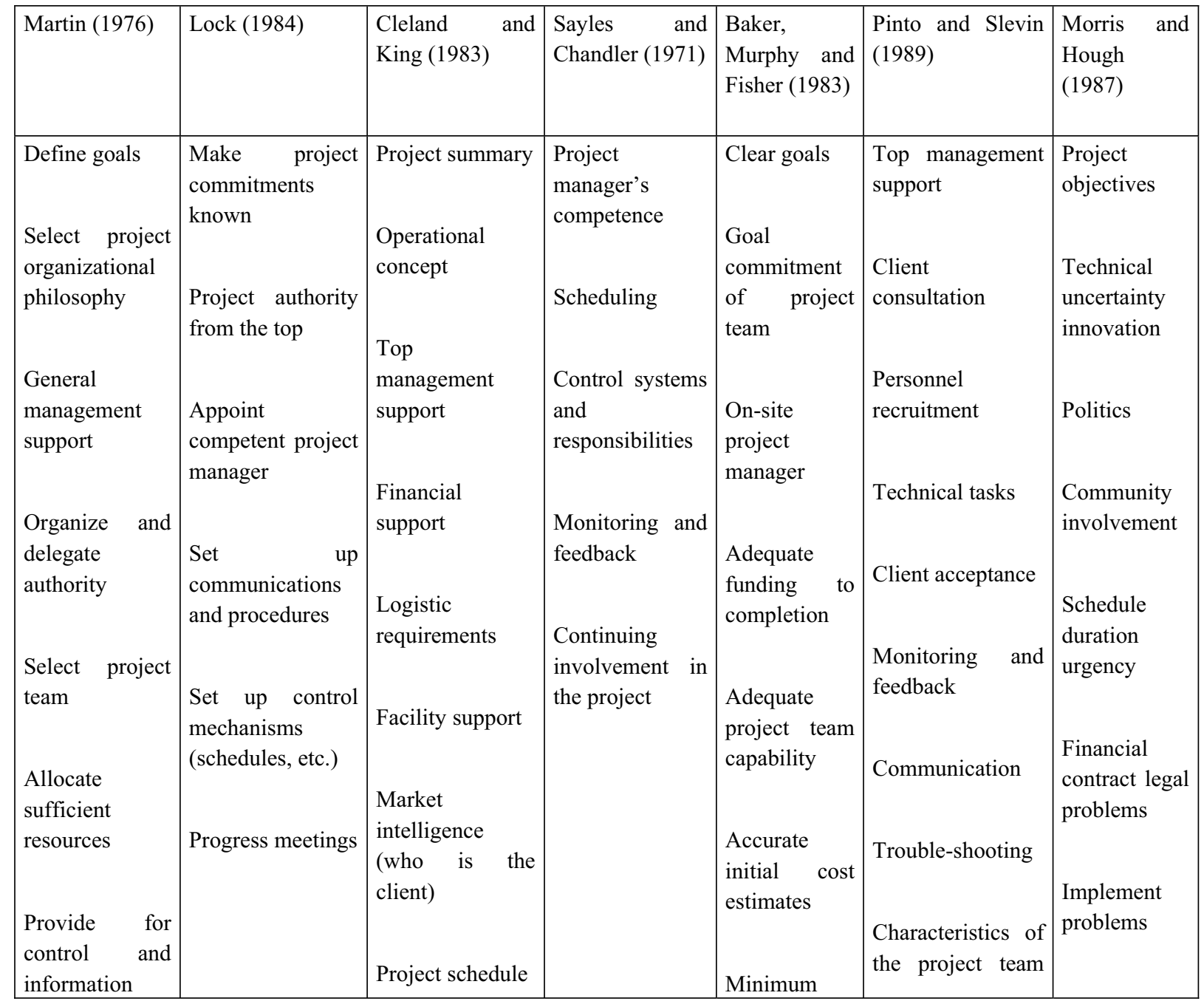




\begin{tabular}{|c|c|c|c|}
\hline $\begin{array}{l}\text { mechanisms } \\
\text { Require } \\
\text { planning and } \\
\text { review }\end{array}$ & 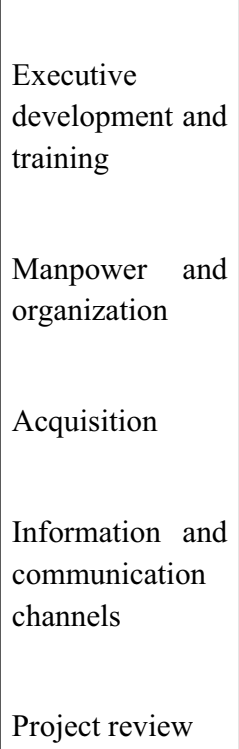 & $\begin{array}{l}\text { start-up } \\
\text { difficulties } \\
\text { Planning and } \\
\text { control } \\
\text { techniques } \\
\text { Task (vs. } \\
\text { social } \\
\text { orientation) } \\
\text { Absence of } \\
\text { bureaucracy }\end{array}$ & $\begin{array}{l}\text { leader } \\
\text { Power and } \\
\text { politics } \\
\text { Environment } \\
\text { events } \\
\text { Urgency }\end{array}$ \\
\hline
\end{tabular}

One of the biggest ways to motivate people and make them more confident of what can be achieved, is through more effective communication. (Toney \& Powers, 1997 and Larkin \& Larkin,1996)

As per Jiang \& Klien et al. (2002), there are ten ways to improve project performance if enterprises in general and project teams in particular implement them:

(1) bypass an obstacle

(2) cause people to stretch, not break

(3) focus on the goal

(4) follow a standardized process

(5) learn from the past

(6) maintaining ongoing communications

(7) record the work being done

(8) reuse previous work

(9) seek buy-in from all involved

(10) seek simplicity, not complexity, in goal and path

Murray, J.P. (2001) describes the nine factors for IT project success that he thinks can make or break IT projects:

(1) appropriate senior management levels of commitment to the project

(2) adequate project funding

(3) a well-done set of project requirements and specifications

(4) careful development of a comprehensive project plan that incorporates sufficient time and flexibility to anticipate and deal with unforeseen difficulties as they arise

(5) an appropriate commitment of time and attention on the part of those outside the IT department who have requested the project, combined with a willingness to see it through to the end

(6) candid, accurate reporting of the status of the project and of potential difficulties as they arise

(7) a critical assessment of the risks inherent in the project, and potential harm associated with those risks, and the ability of the project team to manage those risks

(8) the development of appropriate contingency plans that can be employed should the project run into problems

(9) an objective assessment of the ability and willingness of the organization to stay the project course

A study by Dong et al. (2004) cover most of the concerns of Chinese information systems' project managers, for which they reviewed extensive literature. The most commonly cited set of CSFs are: 
(a) Effective communication

(b) Top management support

(c) User involvement

(d) Project manager and team members

(e) Project definition

(f) Project planning

(g) Project control and change management

(h) Technology support

Therefore a major concern of the field of project management and a recurring theme in the literature is that of project success. The factors that contribute to the success of projects are known as success factors and the success on projects is judged by success criteria. On one hand, the competence of the project manager is in itself a factor in successful delivery of projects and on the other hand, the project manager needs to have competence in those areas that have the most impact on successful outcomes.

\section{Project Success Criteria}

According to Crawford (2002) project success is an important project management issue, it is one of the most frequently discussed topics and there is a lack of agreement concerning the criteria by which success is judged (Pinto and Slevin 1988; Freeman and Beale 1992; Shenhar, Levy, and Dvir 1997; Baccarini 1999).

A review of the literature further reveals that there is, in fact, a high level of agreement with the definition provided by Baker, Murphy, and Fisher (1988), that project success is a matter of perception and that a project will be most likely to be perceived to be an "overall success" if: .......the project meets the technical performance specifications and/or mission to be performed, and if there is a high level of satisfaction concerning the project outcome among key people on the project team, and key users or clientele of the project effort.

There is also a general agreement that although schedule and budget performance alone are considered inadequate as measures of project success, they are still important components of the overall construct. Quality is intertwined with issues of technical performance, specifications, and achievement of functional objectives and it is achievement against these criteria that will be most subject to variation in perception by multiple project stakeholders.

\section{Project Success Factors}

Murphy, Baker and Fisher (1974) used a sample of 650 completed aerospace, construction, and other projects with data provided primarily by project managers on the factors contributing to project success. Theirs have been the most cited, used, extensive and authoritative research in the area of project success factors. They found ten factors that were found to be strongly linearly related to both perceived success and perceived failure of projects, while twenty-three project management characteristics were identified as being necessary but not sufficient conditions for perceived success Baker, Murphy, and Fisher (1988).

Pinto and Slevin $(1987,1988)$ and Morris and Hough $(1986,1987)$ also did an important work on project success factors in the 1980s. While Morris and Hough $(1986,1987)$ drew primarily on literature and case study analysis of major projects, Pinto and Slevin $(1987,1988)$ based their findings on the opinions of a usable sample of 418 PMI members responding to questions asking them to rate the relevance to project implementation success of ten critical success factors and four additional external factors (Slevin \& Pinto 1986).

Therefore, one can conclude that there are umpteen number of factors that may have a bearing on project success. They may differ from one project to another. Following section describes the role of a project manager in achieving project success.

\section{The Project Manager as a Success Factor}

Research has identified that people management drives project success more than technical issues do (Scott-Young \& Samson, 2004). Despite this finding, there exists only a small body of research that examines the so-called soft project management, the people side of project management (Kloppenborg \& Opfer, 2002).

The successful project manager should have the following skills and competencies: flexibility and adaptability, preference for significant initiative and leadership, aggressiveness, confidence, persuasiveness, verbal fluency, ambition, activity, forcefulness, effectiveness as a communicator and integrator, broad scope of personal interests, poise, enthusiasm, imagination, spontaneity, able to balance technical solutions with time, cost, and human factors, well organized and disciplined, a generalist rather than a specialist, able and willing to devote most of his or her time 
to planning and controlling, able to identify problems, willing to make decisions, able to maintain a proper balance in use of time... (Archibald, 1976).

Turner \& Müller $(2004,2005)$ have been studying the impact of project leader and his/her leadership style on project success. The research is still in progress. In the words of Turner \& Müller (2005), "the literature on project success factors has largely ignored the impact of the project manager, and his or her leadership style and competence, on project success. This may be because most of the studies asked project managers their opinion and the respondents have not given due consideration to their own impact on project success. Or, it may be because the studies have not measured the impact of the project manager and, thus, not recorded it. Or, it may be because the project manager has no impact. However, that last conclusion is in direct contrast to the general management literature, which postulates that the leadership style and competence of the manager has a direct and measurable impact on the performance of the organization or business. Thus, the authors have been commissioned by the Project Management Institute to study whether the leadership style and competence of the project manager is a success factor on projects and whether different styles are appropriate on different types of projects."

Almost everyone is familiar with projects perceived as successful by those involved in their implementation, while the very same projects have been poorly received by customers (Pinto \& Slevin 1988). There are other projects that consumed excessive resources and were considered internal failures, but were later hailed as successful by their customers and become a source of revenue for the company for many years (De Wit, 1986). The combination of a changing organizational environment and changing project characteristics make the role of the project leader difficult (Krahn \& Hartman, 2004. Within this environment, a competent project manager is frequently regarded as having a significant impact on overall project success (Ammeter \& Dukerich, 2002; Smith, 1999; Sutcliffe, 1999) as well as being critical to other project elements, such as the success of the project team, including team members' motivation and creativity (Rickards, 2001). This strong link with success ensures that project manager competencies are of particular interest.

\section{Conclusion}

Project manager is an important factor leading to project success. As discussed above, many leading authors agree with this point of view and are conducting research to substantiate this grounded theory. This paper has endeavoured to bring out the factors associated with project manager's leadership style having profound impact on project success.

\section{References}

Ammeter, A. P., \& Dukerich, J. M. (2002). Leadership, team building, and team member characteristics in high performance project teams. Engineering Management Journal, 14 (4), 3-10.

Archibald, R. D. (1976). Managing High Technology Programs and Projects. New York: Wiley and Sons.

Baccarini, D. (1999). The logical framework method for defining project success. Project Management Journal. 30 (4), 25-32.

Baker, B. N., Murphy, D. C., \& Fisher, D. (1988). Factors affecting project success. In: Cleland, D. I. \& King, W. R. (Eds.) Project Management Handbook, second edition pp. 902 - 909. New York: Van Nostrand Reinhold.

Baker, B.N., D.C. Murphy \& D. Fisher. (1983). Factors affecting project success, Project Management Handbook (ed.) D.I. Cleland \& W.R. King, Van Nostrand Reinhold, NY, pp669-685.

Belassi, W., and Tukel, O.I. (1996). A new framework for determining critical success/failure factors in projects. International Journal of Project Management, 14(3), 141-151.

Clarke, A. (1999). A practical use of key success factors to improve the effectiveness of project management, International Journal of Project Management, 17(3), 139-145.

Cleland, D.I. and King, W.R. (1983). Systems analysis and project management. Mc Graw Hill, New York.

Cleland, D.I. (1986). Measuring Success: The owner's viewpoint. Proceedings of the 18th Annual Seminar/Symposium (Montreal/Canada), 6-12. Upper Darby, PA: Project Management Institute.

Crawford, L. (2002). Project Performance Assessment. Masters in Project Management Course, 10th-15th June, Paris, France. UTS/ESC-Lille.

De Wit, A. (1988). Measurement of project success. International Journal of Project Management Vol. 6.

De Wit, A. (1986). Measuring project success: An illusion. Proceedings of the 18th Annual Seminar/Symposium (Montreal/Canada), 13-21. Upper Darby, PA: Project Management Institute. 
Dong, C., Chuah, K.B., \& Zhai, L. (2004). A Study of Critical Success Factors of Information System Projects in China. Proceedings of th PMI Research Conference, London.

Freeman, M., \& Beale, P. (1992). Measuring project Success. Project Management Journal, 23 (1), 8-17.

Gemuenden, H. G. \& Lechler, T. (1997). "Success Factors of Project Management: The Critical Few:An Empirical Investigation”, Portland International Conference on Management of Engineering and Technology pp. $375-377$.

Jiang, J. J., \& Klien, G. et al. (2002). "Pre-project partnering impact on an information system project, project team and project manager." European Journal of Information Systems 11: 86-97.

King, I. (1996). The road to continuous improvement: BPR and Project Management. IIE solutions.

Kloppenborg, T. J. and Opfer, W.A. (2002). The current state of project management research: Trends, interpretations, and predictions. Project Management Journal, 33 (2), 5-18.

Krahn, J., \& Hartman, F. (2004). Important Leadership Competencies for Project Managers: The Fit Between Competencies and Project Characteristics. Proceedings of the PMI Research Conference, London.

Larkin, T.J., \& Larkin, S. (1996). Reaching and changing frontline employees, Harvard Business Review, 74(3).

Lock, D. (1984). Project Management. St Martins press, New York.

Martin, C.C. (1976). Project Management. Amaco, New York.

Morris, P.W.G., \& Hough, G.H. (1987). The anatomy of major projects. John wiley and sons, New York.

Morris, P.W.G., \& Hough, G.H. (1986). The preconditions of success and failure in major projects, Technical Paper \#3, Major Projects Association, Templeton College, Oxford.

Murphy, D., Baker, N. and Fisher, D. (1974). Determinants of Project Success, Boston College, National Aeronautics and Space Administration, Boston.

Murray, J.P., (2001). "Recognizing the Responsibility of a Failed Information Technology Project as a Shared Failure", Information Systems Management, 18 (2): 25-29.

Pinto, J.K., \& Slevin, D.P. (1989). Critical success factors in R\&D projects. Research technology management. pp. 31-35.

Pinto, J. K., \& Slevin, D. P. (1988). Project Success: Definitions and Measurement Techniques. Project Management Journal, 19(1), 67-72.

Radolph, W.A., \& Posner, B.Z. (1994). Effective Project Planning and Management. Prentice Hall International.

Richardson, T. (1995). Project Management pitfalls. Business Communications review, 25(8), 49.

Rickards, T., Chen, M. \&, Moger, S. (2001). Development of a self-report instrument for exploring team factor, leadership and performance relationships. British Journal of Management, 12(3), 243-250.

Rockart, J.F. (1979). “Chief Executives Define Their Own Information Needs,” Harvard Business Review.

Rowe, A. J., Mason, R. O. and Dickel, K. (1982). Strategic management \& business policy, A methodological approach, Addison-wesley publishing company, Philippines.

Sayles, L.R. and Chandler, M.K. (1971). Managing large systems, Harper and Row, New York.

Scott-Young, C. \& Samson, D. (2004). Project Success and Project Team Human Resource Management: Evidence from Capital Projects in the Process Industries. Proceedings of th PMI Research Conference, London.

Shenhar, A.J., Levy, O., \& Dvir, D. (1997). Mapping the dimensions of project success. Project Management Journal. 28 (2): 5-13.

Slevin, D. P., \& Pinto, J. K. (1986). The project implementation profile: New tool for project managers. Project Management Journal, 17 (4): 57-70.

Smith, G. R. (1999). Project leadership: Why project management alone doesn't work. Hospital Material Management Quarterly, 21(1), 88-92.

Stuckenbruck, L.C., (1986). Who determines project success? Proceedings of the 18th Annual Seminar/Symposium (Montreal/Canada), 85-93. Upper Darby, PA: Project Management Institute

Sutcliffe, N. (1999). Leadership behavior and business process reengineering (BPR) outcomes: An empirical analysis of 30 BPR projects. Information \& Management, 36(5), 273-286. 
Toney, F. and Powers, R. (1997). Best practices of project management groups in large functional organizations. Project Management Journal, 33.

Turner, J.R. \& Müller, R. (2005). The project manager's leadership style as a success factor on projects: a literature review. Project management journal. 36 (1). pp. 49-61.

Verma, V. K. (1996). Human resource skills for the project manager. Project Management Institute. Newtown Square, PA.

Verma, V.K. (1995). Organizing projects for success. Project Management Institute. Newtown Square, PA.

Ward, J.A. (1995). Project pitfalls. Information Systems Management. 12(1), 74-76. 